\title{
AGRICULTURE OF THE CZECH REPUBLIC IN THE 21ST CENTURY: FROM PRODUCTIVISM TO POST-PRODUCTIVISM
}

\author{
Antonín VĚŽNíK ${ }^{1}$, Michael KRÁL ${ }^{1}$, Hana SvobodovÁ ${ }^{2}$ \\ ${ }^{1}$ Department of Geography, Faculty of Science, Masaryk University, Brno, Czech Republic \\ ${ }^{2}$ Department of Geography, Faculty of Education, Masaryk University, Brno, Czech Republic
}

Manuscript received: January 13, 2013

Revised version: September 1, 2013

\begin{abstract}
Věžník A., Král M., Svobodová H., 2013. Agriculture of the Czech Republic in the 21st century: From productivism to post-productivism. Quaestiones Geographicae 32(4), Bogucki Wydawnictwo Naukowe, Poznań, pp. 7-14, 8 figs. DOI 10.2478/quageo-2013-0029, ISSN 0137-477X.

AвSTRACT: During last two decades Czech agriculture has gone through significant changes: the transition of agriculture in the 1990s and the entrance of the Czech Republic into the EU and its commitment to the Common Agricultural Policy (CAP). Both of these changes contributed to the structural and regional differentiation of Czech agriculture and exposed it to competition with the whole of Europe. Furthermore, CAP exposed Czech agriculture to uneven conditions for farmers within the EU. The most significant results of these changes have been a decrease in the agricultural sector output, a reduction in farm animals bred, and shrinkage of arable land. On the other hand, many non-productive and non-agricultural activities in the rural areas are subsidised, which offers farmers new possibilities of development. The aim of this paper is to analyse the structural and spatial change in Czech agriculture between 2000 and 2010 on the basis of Agrocenzus data supplemented by opinions of farmers gained in a series of interviews.
\end{abstract}

KEY wORDs: agriculture, EU Common Agricultural Policy, Czech Republic, post-productivism, Agrocenzus

Hana Svobodová, Department of Geography, Faculty of Education, Masaryk University, Pořǐči 7, 60300 Brno, Czech Republic; e-mail: hsvobodova@ped.muni.cz

\section{Introduction}

The changing character of rural areas, changes within agriculture, and a weakening relationship between rural areas and agriculture have been explained for the past twenty years by a number of geographers as a transition from productivism to post-productivism. The change in European rural areas and agriculture over the last thirty years has been examined by several Anglo-Saxon authors, who also describe it as a transition from an era of productivism to the era of post-productivism (Ilbery, Bowler 1998). Some authors speak about a transition to a multifunctional regime of agriculture and rural areas, which would better reflect the currently observed changes. The gist of these discussions is multifunctionality. The concept of multifunctional agriculture or rural areas is a response to significant changes which have taken place here in the last twenty years, both in Western Europe and in the Czech Republic, although the changes occurred (and still do) with differing intensity and timing. Sometimes the changes differ in nature due to differing conditions (mainly political or historical aspects) (Konečný 2013). We can say that the production function of rural areas is now being overshadowed by recreational and residential functions. This drives further change when a previously dominant agricultural sector is increasingly replaced by industry and services 
(in terms of employment of the rural population) (Svobodová et al. 2011).

Czech agriculture has gone through significant changes, including a reduction in employment. During the last 30 years there has been a rapid decline in some livestock species and a change in livestock production structures and methods. The structure of crops and the position of agriculture within the whole food industry has changed. Czech agriculture has gradually become more extensive and ecological, as mentioned by Niggli (2008); however, there are significant regional contrasts with respect to development (cf. Jančák, Götz 1997; Perlín, Hupková 2010; Věžník, Konečný 2011).

This paper follows up on a series of papers about the development of Czech agriculture after the entrance of the Czech Republic into the European Union in 2004 (e.g. Věžník, Konečný 2011; Svobodová, Věžník, 2011 etc.). Similar analyses have been made in all European states. In Slovakia, which had similar initial conditions of agricultural development due to a common history with the Czech Republic, Spišiak (2005) discussed the development of agrostructures, and Neméthová (2009) did the same using the Nitra region as an example. In Poland, Hasiński (1999), Zawalińska (2004), Grykień (2004), Kołodziejczak (2006) and Kołodziejczak and Kossowski (2011) have long studied the development, changes and competitiveness within the agrarian sector. After Poland joined the EU in 2004, these authors have focused on new possibilities in the development of agriculture and on the diversification of activities in rural areas, like tourism, ecological agriculture, and forestry. In spite of differences between Czech and Polish agriculture (the history, farm size, crop structure, etc.), the conditions for diversification are similar.

\section{Materials and methods}

The objective of this paper is to analyse structural and spatial change in Czech agriculture between 2000 and 2010 based on Agrocenzus data, supplemented by farmers' opinions collected in a series of interviews in Czech regions. It reveals some specific problems within the Czech agricultural sector.
Agrocenzus is the only report with results published at the district (NUTS 4) level. All other agricultural data in the Czech Republic are available only for the regional (NUTS 3) level. For the period 2000-2010, the calculated 2010/2000 change index for selected livestock and crops indicates changes in agriculture during those ten years. Index values are illustrated in cartograms. All cartograms have the same unit range (up to $25 \%$ ) for each commodity for good comparability of changes in breeding/cultivation. Selected data are also depicted by a development method, whereby the development of the agrarian sector from 1990 to the present is documented. The main barriers to the development of Czech agriculture in the opinions of farmers (corporate farms and private farmers) are stated at the end of the paper.

\section{Results: Agriculture of the Czech Republic in the 21st century}

Since the Czech Republic entered the European Union in 2004, the overall frame, philosophy, level of support, and level of regulation in agriculture and the agrarian sector have basically conformed to the rules and limitations of the EU Common Agricultural Policy (Bečvářová 2008).

By joining the EU, the Czech Republic gained an opportunity to receive annually significant financial resources for the development of its agriculture. The income of the agricultural sector increased rapidly after the entry, and this funding kept the agricultural sector profitable (in 2010, a total of 6.2 billion Czech korunas, CZK). However, the contribution of agriculture to total GDP has continued to decrease, and so has employment in the agricultural sector. Almost 170,000 people worked in agriculture in 2000 (4.4\% of the economically active population), but this number had fallen to 100,000 by 2010 (2.6\%). Over 60,000 employees have left their job in agriculture since 2000 , whereas approximately 15,000 people have left their jobs in the period of integration of the Czech Republic with the European Union.

The agricultural output, expressed in 1989 prices, fluctuated below 80 billion CZK. The crop output surpassed livestock output (see Fig. 1) and extension type farming spread. The number of livestock decreased in the last twenty years, but 
the livestock yield increased. The expected stabilisation did not happen after the Czech Republic entered the EU; on the contrary, the rate of decrease accelerated for some livestock.

The most significant changes in Czech farming have occurred in livestock production (Fig. 2) when unequal conditions between the old and the new states in the EU, combined with an incorrect distribution of funds, brought about a large reduction in the number of pigs and cattle, causing the Republic to lose its self-sufficiency in meat production. The dependence on the import of these commodities is deepening (Svatoš, Smutka 2012).

Raising cattle is the most demanding sector of livestock production in terms of work, material, and organisation. Despite the falling numbers of livestock, it is still, together with the production of milk, one of the major areas of Czech agriculture. Cattle breeding and milk production are irreplaceable not only from the point of view of agricultural entities, but also of the dependence of crop production on livestock production (the nutrient cycle, crop yield, grassland), employment, and environmental issues of landscape management.

The number of cattle in the Czech Republic fell by almost one-fifth (the index amounting to 84.9) during the examined period and is now the lowest since 1990 (Roubalová, Vodička 2011). The decreasing number of dairy cows contributes significantly to this decline, although the situation has stabilised somewhat after the Czech Republic entered the EU, mainly due to the increasing number of cows without market-production of milk. A grant policy supporting the use of meat cattle for both landscape management (especially in less favoured areas) and production of quality beef has helped to increase the number of cows without market-production of milk. Despite this, the development of the production of meat cattle or beef has been unsatisfactory up to the present day. Stock feeding is not profitable in the long term, yet it remains fundamental for the total output of the sector and cattle farming. The reason for the decline is primarily the situation on the beef market, which causes a large export of cattle, calves, and also beef cattle (at relatively favourable prices) for butchering abroad. The decrease has been the steepest in fertile areas (the Elbe area, south Moravia) where the lower profitability of cattle farming has caused it to be replaced by crop growing and pig farming. The largest decrease has occurred in city districts (Prague, Brno), where the number of cattle is less than a quarter of what it used to be, and in districts near cities (see Fig. 3). An increase has occurred in mountain areas (the north of the Czech Republic) due to an increase in cows without market production of milk. This fact is caused by the agro-environmental CAP measures, which force farmers to put farmland to grass in less favourable areas and use it for pastures where they often raise cattle. A high increase has been attained

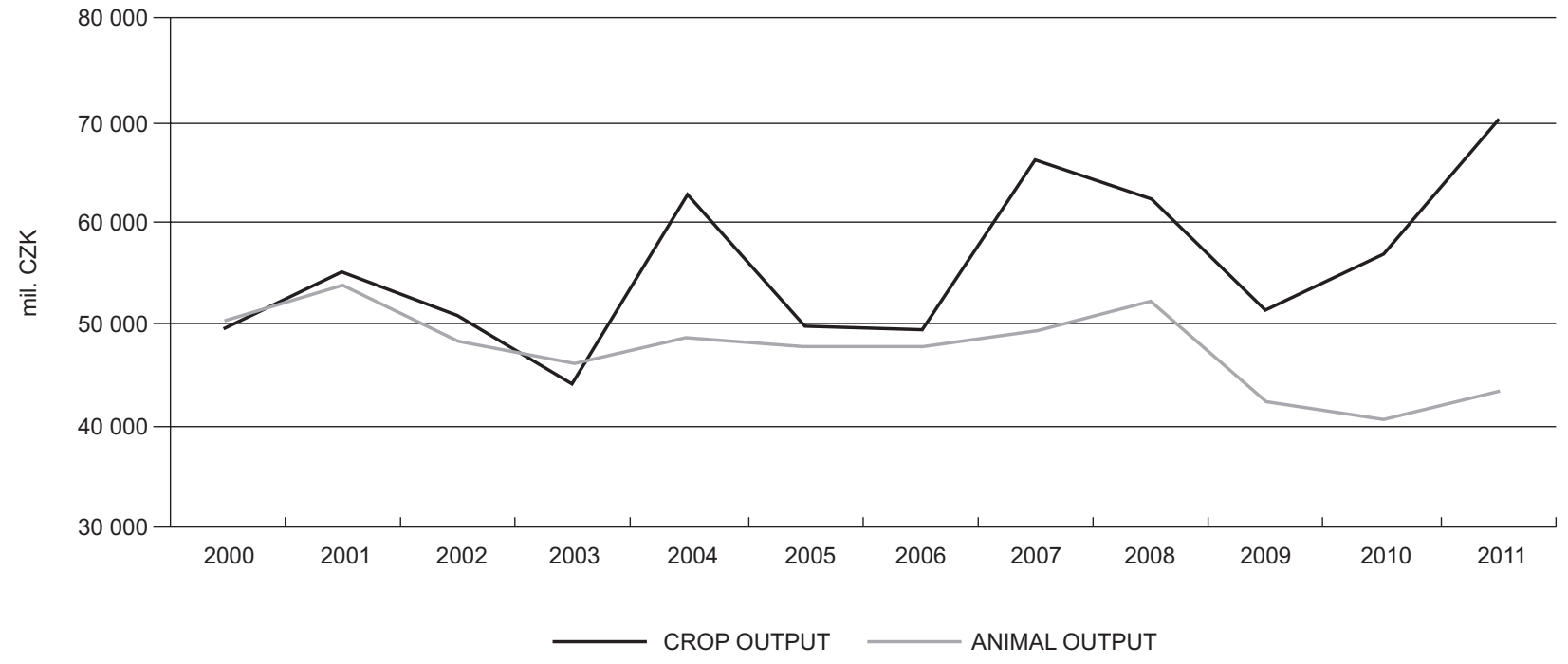

Fig. 1. Crop and animal output in the Czech Republic since 2000. Source: Czech Statistical Office. 


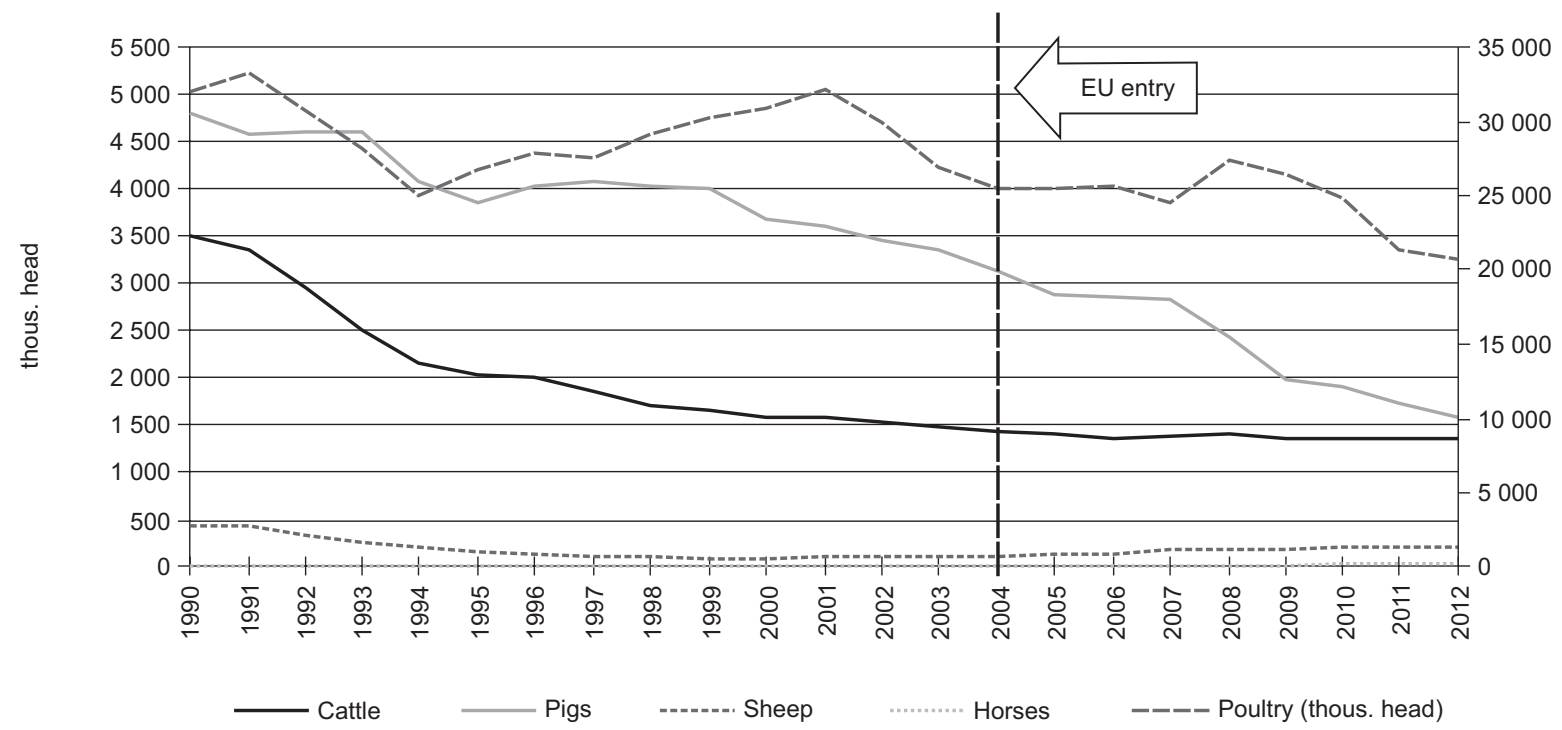

Fig. 2. Head of selected species of animals in the Czech Republic after 1990. Source: Czech Statistical Office.

only in districts where the number of cattle was relatively low and therefore the absolute increase has not been so high (mainly the north-western part of the Czech Republic).

Over the last years there has been a decrease in the number of pigs which started in the 1980s. This trend has rapidly accelerated since 2007. It is due to rising prices of feed, fluctuations in the market price of pork, and the import of cheaper pork and live pigs from abroad; hence many farmers have reduced their pig herds significantly or closed down pig farms altogether (Pavlů, Roubalová 2011). This reduction in pig breeding has occurred in all districts of the Czech Republic except five. A decrease of over $90 \%$ has occurred in four districts (the north-western part of the Republic). In another six (mainly Bohemian), the number of pigs has decreased by 2010 to less than a quarter of the 2000 value. It has decreased by more than half in forty districts, which is more than half of the districts of the Czech Republic.

Changes in crop production have not been so significant; even so, there has been a decrease in the crop area and a substitution of traditional crops (e.g. potatoes, sugar beets) with those that are subsidised (especially rape, partially maize; see Fig. 4).

The most important crops of the Czech Republic are cereals. There was a very moderate decrease (the index at 93.5) during the observed period. The most important cereal is winter wheat, which covers about $55 \%$ of the cereal crop area, with spring wheat covering about $59 \%$. The second most important cereal is spring barley, whose
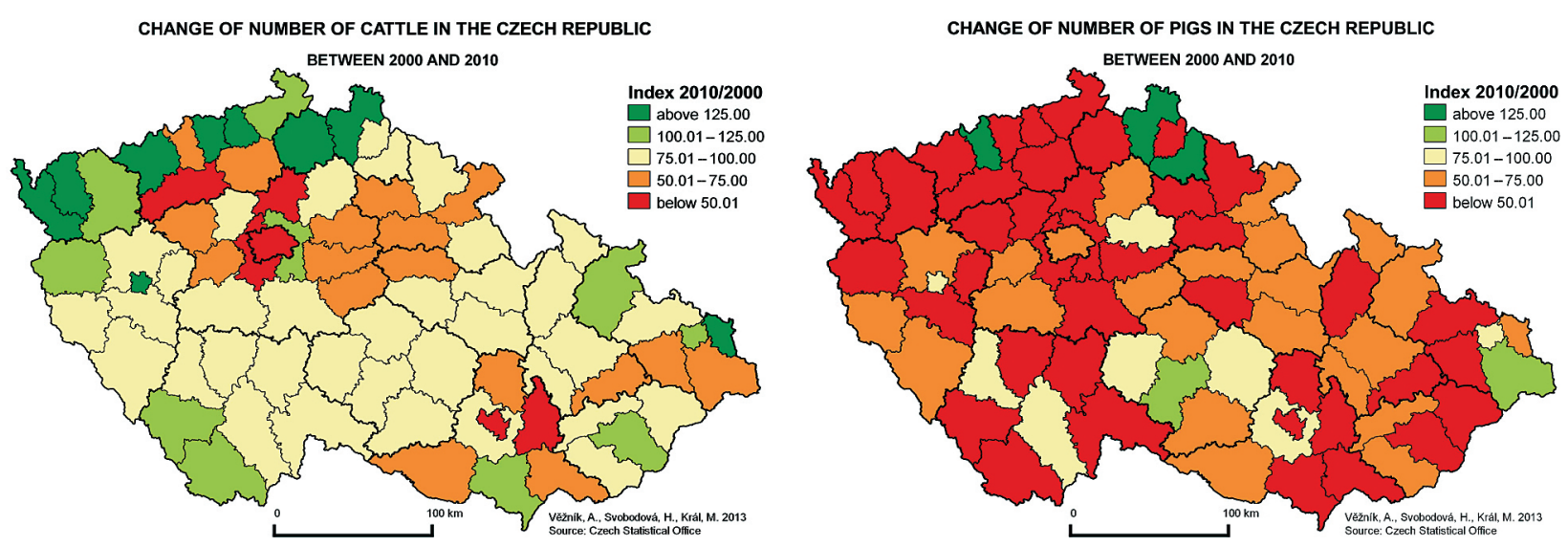

Fig. 3. Change in the number of cattle and pigs in districts of the Czech Republic between 2000 and 2010. Source: Agrocenzus 2000, 2010, own elaboration. 


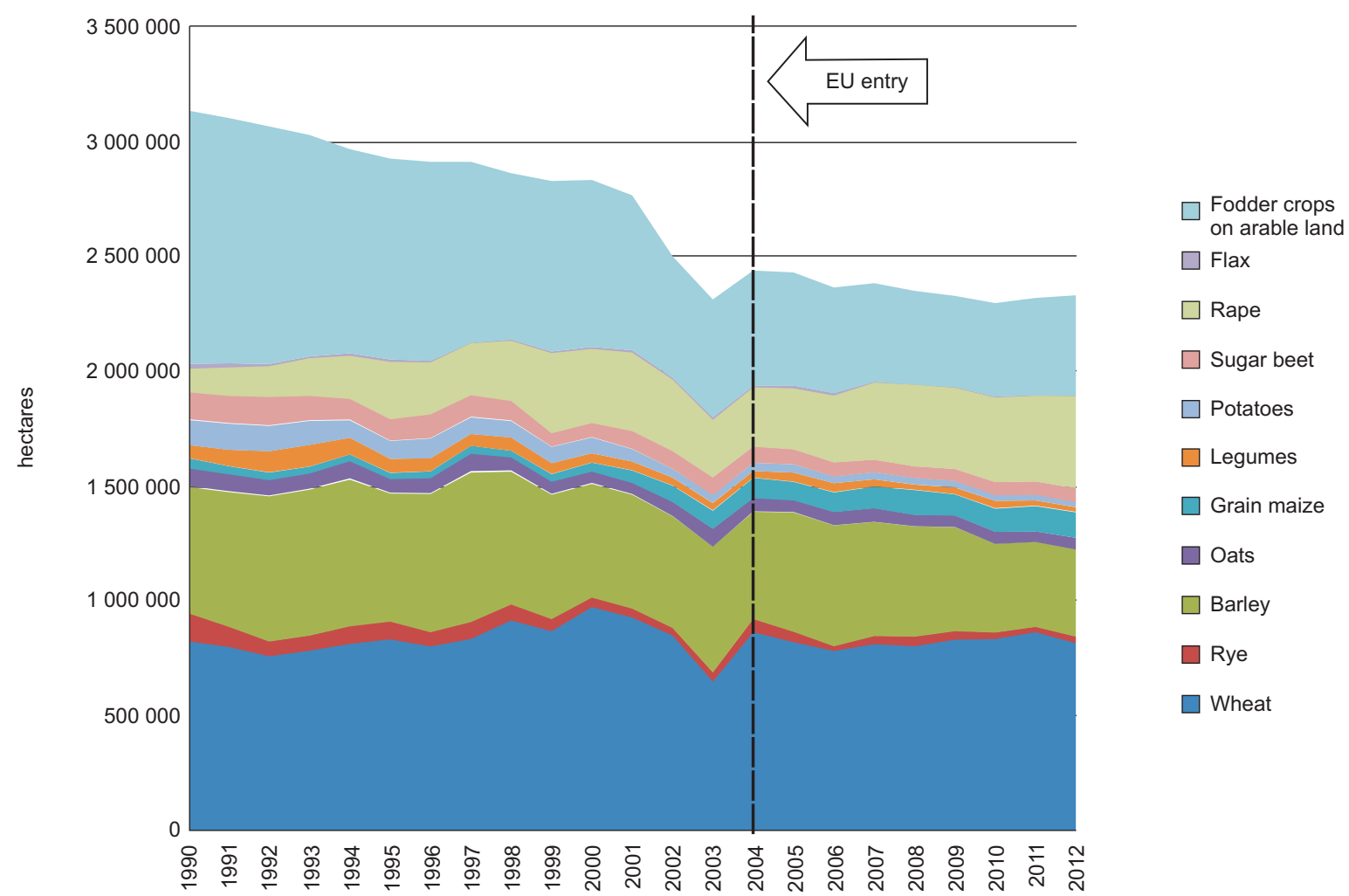

Fig. 4. Area of selected crops in districts of the Czech Republic between 1990 and 2012. Source: Czech Statistical Office.

crop area has decreased and now covers almost $18.5 \%$ of the total cereal crop area. Together with winter barley, they account for about a quarter of the cereal crop area. The amount of maize for grain is rising and takes up about $7.5 \%$ of the area. The other cereals have marginal importance in general terms, but may be more important at a regional level (Kůst, Potměšilová 2011). The most significant decrease in the area of cereals has been recorded in districts at higher elevations, where the shrinkage of arable land has been more significant. The largest increase has been noted in districts with the best conditions for growing cereals, especially the south Moravian and Haná districts, but also in regions where the landscape has been reclaimed and the land under cereals has grown together with farmland (see Fig. 5).

The area under potatoes in the Czech Republic dwindled by about one-third between 2000 and 2010 (the index at 62.7) due to rising yields and a lower consumption of potatoes, especially of potato starch, and potatoes as livestock feed (Fig. 6). The crop area increased in districts where production of potatoes is less important and the area is small; therefore even a small increase in the crop area makes it relatively high. A signif- icant decline has been noted in districts where potato production is traditional and where the crop area is large (the central part of the Republic). The potato crop area has shrank to less than a quarter in thirteen districts and less than a half in forty-three districts, which is more than half of the districts of the Czech Republic.

The sugar beet crop area slightly decreased in the Czech Republic between 2000 and 2010 (the index at 94.1). Sugar production was roughly at

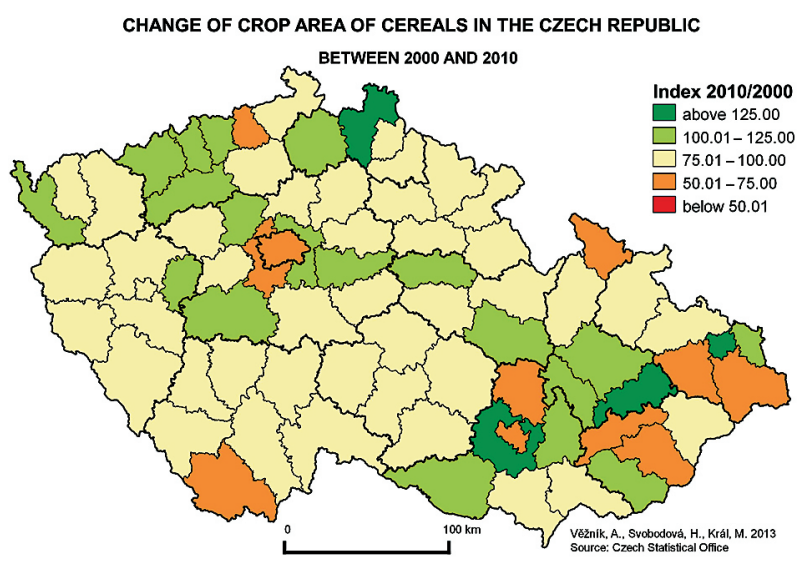

Fig. 5. Change in the crop area of cereals in districts of the Czech Republic between 2000 and 2010. Source: Agrocenzus 2000, 2010, own elaboration. 

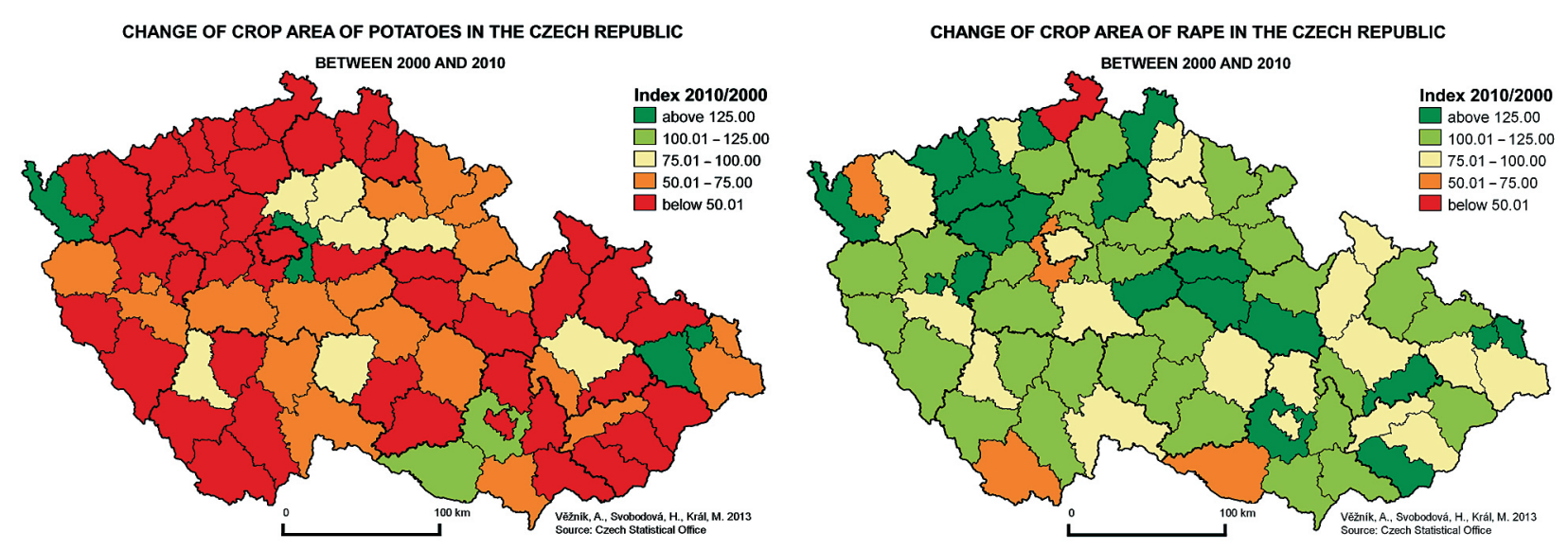

Fig. 6. Change in the crop area of potatoes and rape in districts of the Czech Republic between 2000 and 2010. Source: Agrocenzus 2000, 2010, own elaboration.

the same level and the yield increased slightly between 2000 and 2010, therefore the crop area did not change significantly. The major areas of sugar beet production are lowlands close to sugar refineries (Adamec, Franěk 2011).

In response to these changes the use of land has changed. The area of arable land has decreased in the Czech Republic, as well as in other states with developed agriculture. The country's $2010 / 2000$ index is 91.2 .

Arable land dwindled in most districts of the Czech Republic during the observed period (Fig. 7). City districts (Prague, Brno), where arable land was used for residential buildings, industry, and transport infrastructure, or mountain areas where it had been grassed over, noted the greatest reduction. There was also a large decrease in districts at higher elevations and steeper slopes where arable land had been substituted by per-

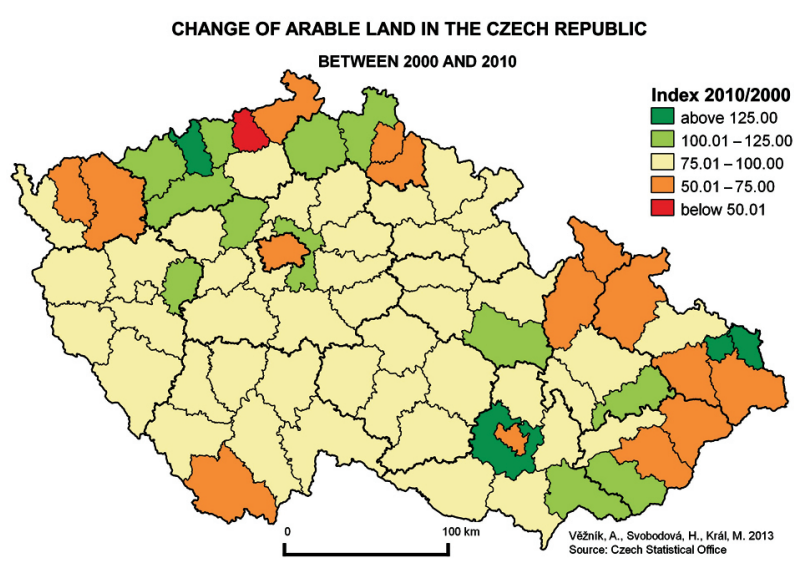

Fig. 7. Change in arable land in districts of the Czech Republic between 2000 and 2010

Source: Agrocenzus 2000, 2010, own elaboration. manent meadows and pastures, or afforested (Budňáková 2009). Conversely, an increase in arable land was recorded in districts where there used to be heavy industry and coal mining (the Ostrava region, north-western Bohemia). The land there had been reclaimed and partly transformed into arable land.

\section{Barriers to the development of Czech agriculture}

Apart from the livestock production issue and the small change in the crop production structure, the entrance of the Czech Republic to the European Union has brought a number of other problems which farmers must deal with. As found from a series of interviews with farmers, these issues have a different impact on corporate farms and on private farmers. Fig. 8 presents the results of surveys in the Vysočina region in 2010, where 114 farmers (from 47 corporate and 67 private farms) were interviewed.

Corporate farms perceive the greatest barrier to development to be the low protection level of the domestic agricultural products market, administration, and problems with purchasers and their payments. Private farmers perceive administration problems as the biggest barrier to development. This could be explained by the contrast between corporate farms and private farmers. Private farmers have no support for statement and request processing and this work represents a large burden for them. Low protection of the domestic agricultural products market is the sec- 

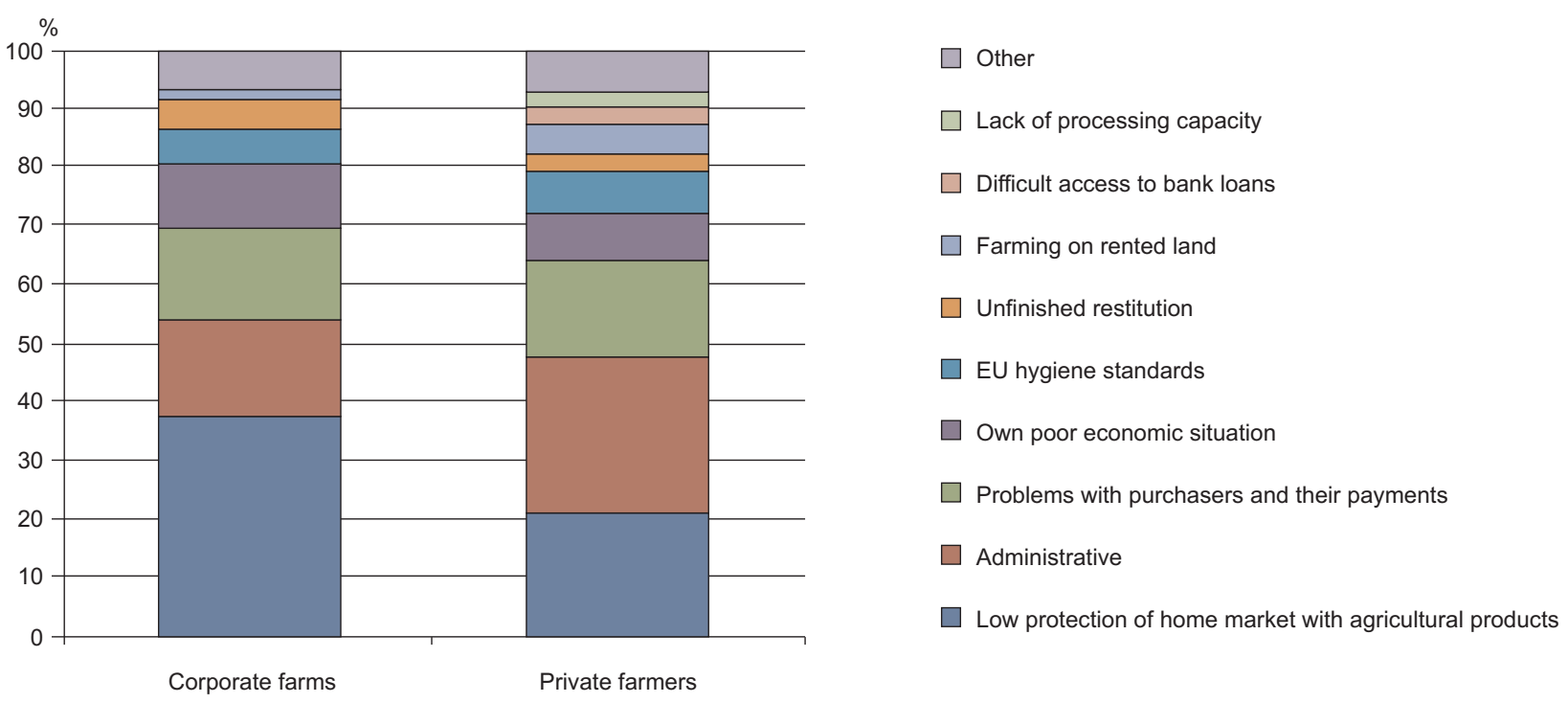

Fig. 8. Barriers of agriculture development in corporate and private farms.

Source: own questionnaire survey.

ond barrier, and troubles with purchasers and their payments is the third. There are also concerns expressed by private farmers which did not affect corporate farms: difficult access to bank loans and lack of a processing capacity. Unequal conditions for the new and the old EU states were indicated by both corporate and private farmers as being a significant problem.

Farmers often see an increase in financial resources as positive. Paradoxically, according to the survey, $85 \%$ of corporate farms and $81 \%$ of private farmers would not be able to farm without funding.

\section{Conclusions}

Czech agriculture and related sectors have gone through a fundamental change since 1989, which was necessitated by changes in the socio-economic situation. The response to the entrance of the Czech Republic to the EU and the period after this entrance were fundamental. Agriculture had to adapt not only to conditions of the common EU market, but also to the conditions of a globalising world market.

Profits in agriculture increased rapidly after joining the EU due to the rise in funding which maintained agricultural profitability; however, the total volume of agricultural output decreased significantly. The Czech Republic has lost food self-sufficiency and the problem of uncultivated land reappeared. Import of cheap agricultural products from abroad has affected the development of agriculture recently (Svatoš, Smutka 2009). The decrease in employment in agriculture and related sectors as well as low salaries in agriculture has also affected rural development (similarly to the situation in Poland, cf. Kołodziejczak, Kossowski 2011). To preserve some dimension of agriculture, it will be important to support a lifestyle and activities in rural areas, invest in the diversification of the activities, generate new jobs, support the involvement of young people in rural areas, and complete appropriate infrastructure. Also important will be better preservation of farmland, water sources, landscape, and biodiversity. Those are important tasks for agricultural entities which must be retained.

Further development of the agrarian sector will be affected by the setting of CAP in the period 2014+, not only in the Czech Republic, but across the whole of the EU. The proposed changes do not look optimistic for the Czech Republic. For example, the change implemented in the Czech Republic in 2012 (a decrease in the total amount of all direct payments by over $€ 300,000$ ) already puts Czech farmers at a disadvantage. The CAP does not respect different conditions in member states, mainly those which are based on high-volume agricultural production. The future setting of the CAP is still being discussed, and the ques- 
tion is what consensus will the member countries work out.

\section{References}

Adamec R., Franěk D., 2011. Situační a výhledová zpráva: Cukr, cukrová řepa (Situation and outlook report: Sugar, sugar beet). Ministerstvo zemědělství ČR, Praha.

Agrocenzus 2000. Czech Statistical Office, Praha.

Agrocenzus 2010. Czech Statistical Office, Praha.

Bečvářová V., 2008. Vývoj českého zemědělství v evropském kontextu (Development of Czech agriculture in the European context). Mendlova zemědělská a lesnická univerzita $v$ Brně, Brno.

Budňáková M., 2009. Situační a výhledová zpráva: Půda (Situation and outlook report: Land). Ministerstvo zemědělství ČR, Praha.

Grykień S., 2004. Przeksztatcenia w rolnictwie Europy Środkowo-Wschodniej ze szczególnym uwzględnieniem nowych krajów związkowych Niemiec, Polski i Ukrainy (Transformation of agriculture in Central and Eastern Europe with special emphasis on new federal states of Germany, Poland and Ukraine). Wydawnictwo Universytetu Wrocławskiego, Wrocław.

Hasiński W., 1999. Rolnictwo indywidualne na Dolnym Śląsku $w$ okresie transformacji systemowej (Individual agriculture in Lower Silesia during the systemic transition). Uniwersytet Wrocławski, Wrocław.

Ilbery B.W., Bowler I.R., 1998. From agricultural productivism to post-productivism. In: Ilbery B. (ed.), The geography of rural change. Longman, Essex: 57-84.

Jančák V., Götz A., 1997. Územní diferenciace českého zemědělství a její vývoj (Spatial differentiation of Czech agriculture and its development). Př́rodovědecká fakulta Univerzity Karlovy, Praha.

Kołodziejczak A., 2006. Agriculture and the countryside in Poland: alternative scenarios of change. Quaestiones Geographicae 25(B): 47-52.

Kołodziejczak A., Kossowski T., 2011. Diversification of farming systems in Poland in the years 2006-2009. Quaestiones Geographicae 30(2): 49-52.

Konečný O., 2013. Multifunkcionalita: geografie, venkov, zemědělství (Multifunctionality: Geography, rural areas, agriculture). Sborník z Výroční konference České geografické společnosti. Masarykova univerzita, Brno: 182-189.

Kůst F., Potměšilová J., 2011. Situační a výhledová zpráva: Obiloviny (Situation and outlook report: Cereals). Ministerstvo zemědělství ČR, Praha.

Némethová J., 2009. Agropotravinárské štruktury okresu Nitra (Agrifood structure of the Nitra district). Univerzita K. F. Nitra, Prír. fakulta. Nitra.

Niggli U., 2008. Ekologické zemědělství - cesta pro udržitelnost $\mathrm{v}$ zemědělské praxi (Organic farming - the way for sustainability in agricultural practice). In: Šarapatka B., Niggli U. (eds), Zemědělství a krajina: cesty $k$ vzájemnému souladu. Univerzita Palackého, Olomouc.

Pavlů M., Roubalová M., 2011. Situační a výhledová zpráva: Veprové maso, drůbež a vejce (Situation and outlook report: Pork, poultry and eggs). Ministerstvo zemědělství ČR, Praha.

Perlín R., Hupková M., 2010. Venkovy a venkované (Rural areas and villagers). Univerzita Karlova, Praha.

Roubalová M., Vodička J., 2011. Situační a výhledová zpráva: Skot - hovězi maso (Situation and outlook report: Cattle beef). Ministerstvo zemědělství ČR, Praha.

Spišiak P., 2005. Agrorurálne štruktury Slovenska po roku 1989 (Agrorural structures of Slovakia after 1989). Geografika, Bratislava.

Svatoš M., Smutka L., 2009. Influence of the EU enlargement on the agrarian foreign trade development in member states. Agricultural Economics 55(5): 233-249.

Svatoš M., Smutka L., 2012. Development of agricultural trade and competitiveness of the commodity structures of individual countries of the Visegrad Group. Agricultural Economics 58(5): 222-238.

Svobodová H., Věžník A., 2011. Impacts of the Common Agricultural Policy of the European Union in the Vysočina region (Czech Republic) by the view of the farmers. Journal of Central European Agriculture 12(4): 726-736. DOI: 10.5513/JCEA01/12.4.982

Svobodová H., Konečný O., Binek J., Chabičovská K., Holeček J., Galvasová I., Věžník A., Hynek A., 2011. Synergie ve venkovském prostoru (Synergies in rural areas). GaREP, Brno.

Věžník A., Konečný O., 2011. Agriculture of the Czech Republic after accession to the EU: Regional differentiation. Moravian Geographical Reports 19(1): 50-60.

Zawalińska K., 2004. The competitiveness of Polish agriculture in the context of integration with the European Union. UW, Warszawa. 